\title{
Anthracycline-associated cardiotoxicity in adults: systematic review on the cardioprotective role of beta-blockers
}

\author{
Roberto Ramos Barbosa ${ }^{1}$ \\ Taissa Borges Bourguignon ${ }^{1}$ \\ Luíza Dias Torres ${ }^{1}$ \\ Lorenza Silveira Arruda ${ }^{1}$ \\ Tiago de Melo Jacques ${ }^{1}$ \\ Renato Giestas Serpa ${ }^{1}$ \\ Osmar de Araujo Cali'1 \\ Luiz Fernando Machado Barbosa ${ }^{1}$
}

1. School of Sciences of Santa Casa de Misericórdia de Vitoria, Vitória, ES, Brasil

http://dx.doi.org/10.1590/1806-9282.64.08.745

\section{SUMMARY}

OBJECTIVES: This study aimed at assessing the role of beta-blockers on preventing anthracycline-induced cardiotoxicity in adults. METHODS: A systematic review was performed on electronic databases, including relevant studies that analysed beta-blockers as cardioprotective agents before the use of anthracyclines by adult oncologic patients.

RESULTS: After application of eligibility and selection criteria, eight articles were considered as high quality, complying with the proposed theme; all eight clinical trials, four of them placebo-controlled, with a total number of 655 patients included. From this sample, 281 (42.9\%) used beta-blocker as intervention, and carvedilol was the most frequent (167 patients - 25.5\%). Six studies were considered positive regarding the cardioprotection role played by beta-blockers, although only four demonstrated significant difference on left ventricle ejection fraction after chemotherapy on groups that used beta-blockers compared to control groups. Carvedilol and nebivolol, but not metoprolol, had positive results regarding cardioprotection. Other beta-blockers were not analysed in the selected studies.

CONCLUSIONS: Despite the potential cardioprotective effect of beta-blockers, as demonstrated in small and unicentric clinical trials, its routine use on prevention of anthracycline-associated cardiotoxicity demands greater scientific evidence.

KEYWORDS: Cardiotoxicity. Anthracyclines. Heart failure. Heart diseases/prevention \& control.

\section{INTRODUCTION}

Anthracyclines (doxorubicin, daunorubicin, epirubicin and idarubicin) are chemotherapeutic drugs that act as potent antineoplastic agents. After its introduction into the therapeutic arsenal of oncology, survival rates of cancer patients increased from $30 \%$ to $70 \%^{1}$. Unfortunately, despite its effectiveness, one of its consequences is cardiac failure ${ }^{1,2}$. As the replacement of anthracyclines by other chemotherapeutic agents are often infeasible from a therapeutic perspective, the deprivation of this drug could negatively influence the prognosis of the tumour and the patient survival.

Among the mechanistic hypotheses of induction of cardiotoxicity by anthracyclines are apoptosis, 
mitochondrial dysfunction, activation of the metalloproteinases matrix and formation of oxygen free radicals. ${ }^{2,3}$ The main cardiotoxic effects of anthracyclines are related to higher cumulative doses, however, higher doses lows can also be harmful. Left ventricular diastolic dysfunction is usually seen in cumulative doses of $200 \mathrm{mg} / \mathrm{m}^{2}$, while systolic dysfunction is seen at cumulative doses above $400 \mathrm{mg} /$ $\mathrm{m}^{2}{ }^{4}$ The intracellular biochemical mechanisms of anthracycline-induced cardiotoxicity are illustrated in Figure 1.

The use of potent antiemetic agents and granulocyte colony stimulating factors decreased the occurrence of the most common adverse effects, which resulted in the use of higher doses of anthracyclines in treatments, predisposing to the cardiac damages known today ${ }^{5}$. Both the symptomatic phase and the asymptomatic phase of heart failure induced by chronic cardiotoxicity of doxorubicin are associated with a worse prognosis, with a mortality rate of up to $50 \%$ in one year. ${ }^{6,7}$

Beta-blockers promote neurohumoral regulation in the presence of cardiac dysfunction, leading to positive remodelling of the left ventricle, which reduces mortality in heart failure. ${ }^{8}$ Some have antioxidant and free radical removal function. ${ }^{7}$ Their pharmacological mechanism suggests a cardioprotective function, however, there are still no recommendations for their use in prevention of anthracycline-induced cardiotoxicity. The objective of this study was to conduct a systematic review of the cardioprotective role of beta-blockers in preventing anthracycline-induced cardiotoxicity in adults.

\section{METHODS}

A descriptive study was carried out, consisting of a systematic review of the literature. The research was carried out in the databases MedLine/PubMed, Embase, ISI Web of Knowledge, Latin American and Caribbean Literature in Health Sciences (Lilacs) and Scientific Electronic Library Online (SciELO), in which several combinations of terms related to the topic were used, including derivations. The filter humans was used to limit the search, excluding experimental animal studies and in vitro tests. Articles listed in the references have also been identified and reviewed. The search strategy used for the MedLine/ PubMed database and replicated to the other databases is in Appendix 1.

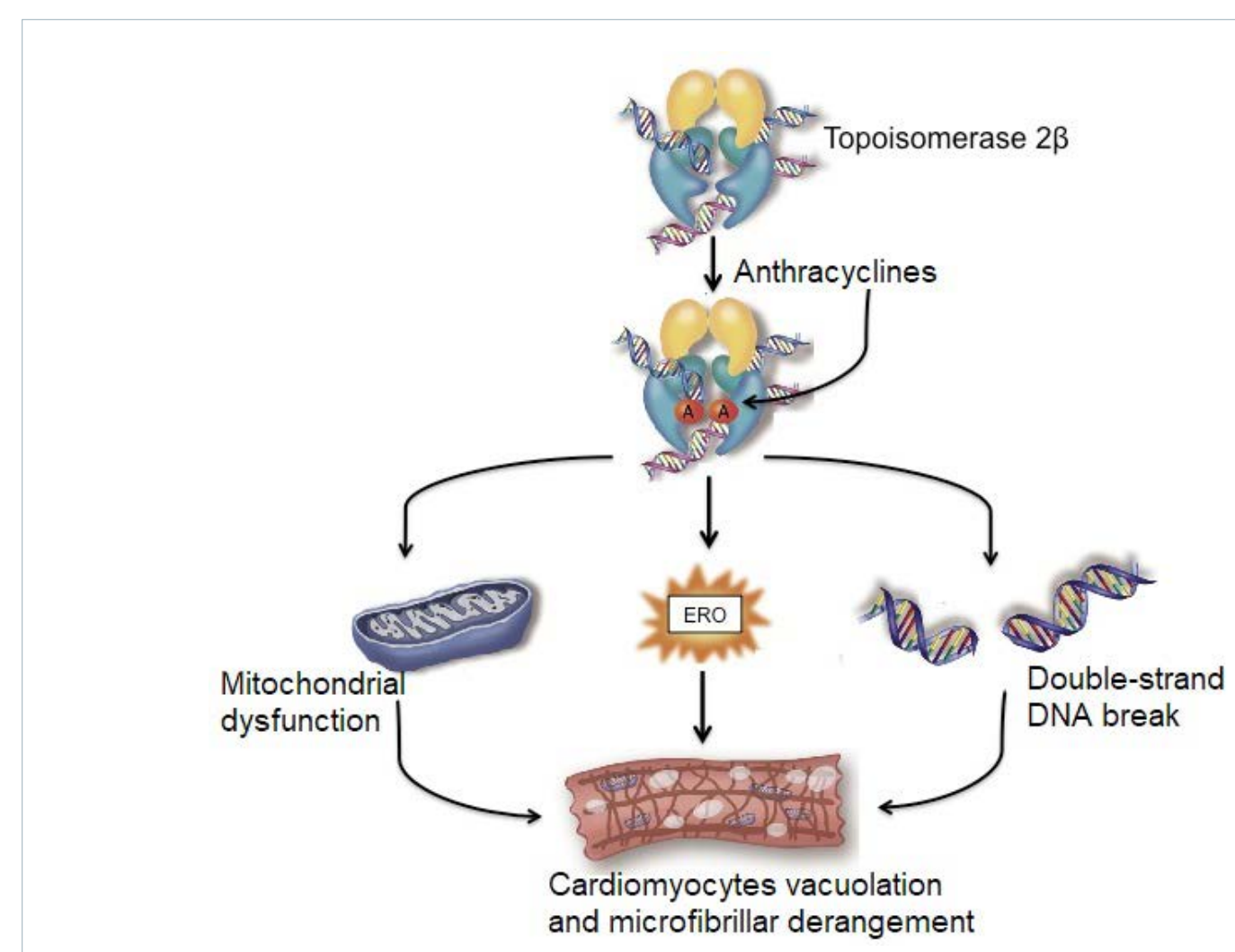


Studies could include, in addition to adults, paediatric populations. However, studies with only patients younger than 18 years old were excluded. Studies focusing on the diagnosis or treatment of anthracycline-induced cardiotoxicity, rather than on its primary prevention, were also excluded, as well as studies analysing non-beta-blocking drugs as a strategy to prevent anthracycline cardiotoxicity. Studies that included other chemotherapeutics in their analysis could be included in the review, provided that an anthracycline had also been analysed. The included studies could be clinical trials, cohort studies, historical cohorts or case-control studies, originally published in any language, provided they also had a publication in the English or Spanish language. There was no restriction of publication date. Articles published up to April 10, 2017 (date of search) could be included. Articles such as Simple Revision/Narrative, Editorial, Letter to the Editor, Short Communication, Preliminary Communication or Case Report were excluded. Since this was a systematic review, it did not require approval from the institution's Research Ethics Committee.

For the analysis and selection of the articles to be included in the review, the articles titles were initially evaluated based on the search strategy in the electronic databases, with a subsequent evaluation of the studies abstracts that contemplated the subject. The articles considered pertinent to the subject were read in full, to be then excluded the articles considered outside the topic or with a design out of the inclusion criteria. In this process, two reviewers participated independently, reaching a consensus when there was disagreement. Preferred Reporting Items for Systematic Reviews and Meta-Analyses (Prisma) criteria was used in the eligibility of articles found for inclusion in the systematic review. ${ }^{9}$ No meta-analysis was performed. The results of the studies were described in a descriptive way by drugs of the beta-blockers. Biases were considered and analysed individually for each study included.

\section{RESULTS}

From the keywords used in the search strategy, 790 articles were found. Delimiting the topic from the title, 576 articles were excluded (different population, different chemotherapeutics or different intervention medications), and 214 articles were then screened. Of these, after reviewing the abstract, 78 articles were excluded due to duplication in the electronic databases search, and 101 articles because they

\section{FIGURE 2}

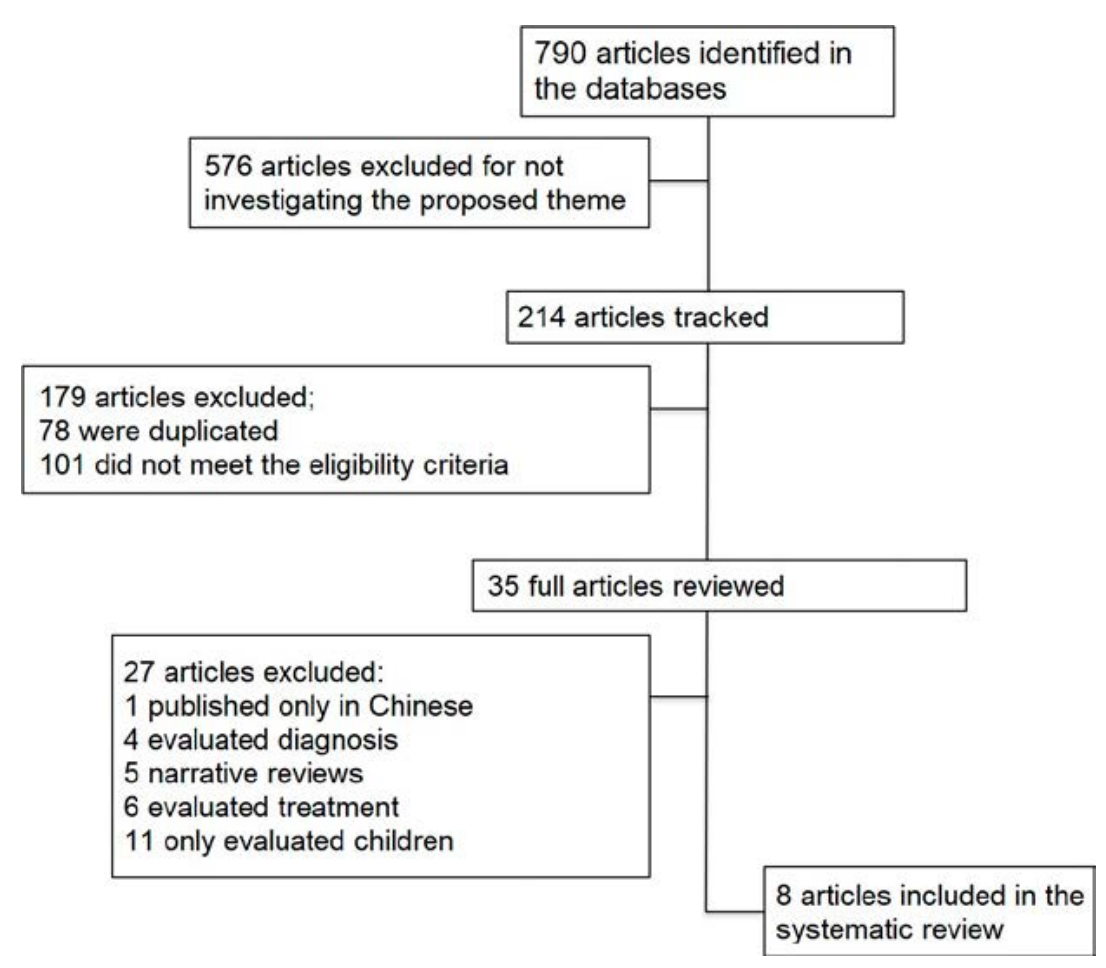


did not meet the eligibility criteria (case reports, case series, experimental studies, animal studies, treatment research, chemotherapy not including anthracyclines), leaving 35 articles for full analysis. After reading the complete text, 27 were excluded because they did not fit the inclusion criteria regarding the design, research proposal and quality of evidence, remaining eight articles that met the inclusion criteria and were included in the systematic review. ${ }^{10-17}$ Relevant articles were screened and analysed according to the flowchart contained in Figure 2.

The eight articles selected consist of unicentric randomized clinical trials, four of them being placebo-controlled trials (Kalay et al. ${ }^{10}$, Kaya et al., ${ }^{12}$ Tashakori Beheshti et al., ${ }^{15}$ Gulati et al. ${ }^{17}$ ), and four with control group without placebo or any other intervention (Georgakopoulos et al.," ${ }^{11}$ Bosch et al., ${ }^{13}$ Jhorawat et al., ${ }^{16}$ and Elitok et $\left.\mathrm{al}^{14}\right)$. The study by Bosch et al. ${ }^{13}$ analyzed the intervention with two combined drugs (carvedilol and enalapril), and Georgakopoulos et al. ${ }^{11}$ also evaluated two drugs: metoprolol and enalapril, but in separate groups, compared to the control group. The study by Gulati et al. ${ }^{17}$ evaluated the use of metoprolol and candesartan, in combination and separately (associated with placebo), and included a control group that received two placebos. The other five studies compared one group with administration of a beta-blocker to a control group with or without placebo.

A total of 655 research participants were included in the eight studies, of which 281 (42.9\%) used a beta-blocker drug, while 115 (17.5\%) used placebo and 184 (28.1\%) did not receive medication as intervention or placebo (control group without placebo). The remaining 75 patients (11.4\%) used another drug to be evaluated as cardioprotective intervention: 43 (6.5\%) used enalapril and 32 (4.9\%) used candesartan.

Among the patients who received beta-blockers, 27 (4.1\%) used nebivolol, 87 (13.3\%) used metoprolol, 30 (4.6\%) used metoprolol in combination with candesartan, 167 (25.5\%) used carvedilol and 45 (6.9\%) used carvedilol in combination with enalapril.

In the eight articles included, the primary outcome consisted of changes in echocardiographic parameters, mainly left ventricular ejection fraction (LVEF) and left ventricular systolic and diastolic diameters. Two of the studies performed longitudinal strain and left ventricular myocardial strain rate analysis using tissue Doppler, including those findings at the primary outcome (Tashakori Beheshti et al. ${ }^{15}$ and Elitok et al. ${ }^{14}$ ). Another study (Bosch et al. ${ }^{13}$ ) evaluated, in addition to the echocardiogram, troponin I and brain natriuretic peptide (BNP) values, and cardiac magnetic resonance imaging.

Two studies also evaluated mortality as a secondary outcome (Jhorawat et al. ${ }^{16}$ and Kalay et al. ${ }^{10}$ ), in which, respectively, $22.2 \%$ and $4.0 \%$ of carvedilol patients died at follow-up, while mortality in the control group was $18.5 \%$ and $16.0 \%$, with no statistically significant difference for this comparison in the two studies. In both, however, there was no differentiation of the cause of the deaths, and it was not possible to distinguish the cardiovascular mortality from that occurred by the neoplasia or its complications. The study by Georgakopoulos et al. ${ }^{11}$ did not describe the mortality among the outcomes analysed, but it describes, in the results, that no patient died or stopped chemotherapy due to cardiotoxicity.

The beta-blockers used in the included articles were administered under different therapeutic regimens at different doses, always before the start of chemotherapy. Clinical follow-up was performed for up to 31 months in the study by Georgakopoulos et al.,"1 with great heterogeneity regarding the follow-up time in the sample analysed. In the study by Tashakori Beheshti et al., ${ }^{15}$ the follow-up time was not explained, despite description of the protocol of four consecutive cycles of chemotherapy, with a duration of 21 days each. In the other studies included, clinical follow-up was done for six months.

Six studies analysing beta-blockers as cardioprotective agents in anthracycline chemotherapy were positive, with superiority of medication use over placebo or no medication. In two of these (Tashakori Beheshti et al. ${ }^{15}$ and Elitok et al. ${ }^{14}$ ), there was no difference in relation to LVEF between the intervention and control groups, but the studies were considered positive by changes in strain parameters in all walls (Tashakori Beheshti et al. ${ }^{15}$ ) or most of the ventricular walls (Elitok et al. ${ }^{14}$ ), observed in the control group compared to the intervention group. Thus, in the four studies that showed a difference in the mean final LVEF between the intervention and control groups, the differences were, in percentage points, 17.4 (Kalay et al. ${ }^{10}$ ), 6.3 (Kaya et al..$^{12}$ ), 3.1 (Jhorawat et al. ${ }^{16}$ ) and 3.1 (Bosch et al. ${ }^{13}$ ). General information on each study, designs, results and methodological characteristics capable of generating biases are set out in Table 1. Analysis of each beta-blocker drug and its results in the included studies is set out in Table 2. 
TABLE 1. ANALYSIS OF STUDIES INCLUDED IN THE SYSTEMATIC REVIEW, IN CHRONOLOGICAL ORDER OF PUBLICATION

\begin{tabular}{|c|c|c|c|c|}
\hline Author, publication year & City, Country & Intervention (N) & Comparison (N) & Results and data \\
\hline Kalay et al., 200610 & Kayseri, Turkey & Carvedilol (25) & $\begin{array}{l}\text { Control group with } \\
\text { placebo (25) }\end{array}$ & $\begin{array}{l}\text { Intervention was superior. } \\
\text { Initial LVEF and after six months: Carvedilol } \\
\text { Group }=70.5 \% \text { vs. } 69.7 \%, p=0.3 ; \text { Control } \\
\text { Group }=68.9 \% \text { vs. } 52.3 \% ; p=0.001 .\end{array}$ \\
\hline $\begin{array}{l}\text { Georgakopoulos et al., } \\
201011\end{array}$ & Athens, Greece & Metoprolol (25) & $\begin{array}{l}\text { Control group without } \\
\text { placebo (40) and Enal- } \\
\text { april group (43) }\end{array}$ & $\begin{array}{l}\text { No difference. } \\
\text { LVEF after } 12 \text { months: Metoprolol Group } \\
=63.3 \% \text {, Enalapril Group }=63.9 \% \text {, Control } \\
\text { Group }=66.6 \% ; p=0.06\end{array}$ \\
\hline Kaya et al., 201312 & Kayseri, Turkey & Nebivolol (27) & $\begin{array}{l}\text { Control group with } \\
\text { placebo (18) }\end{array}$ & $\begin{array}{l}\text { Intervention was superior. } \\
\text { LVEF after six months: Nebivolol Group } \\
=63.8 \% \text {, Control Group }=57.5 \% ; p=0.01 \text {. } \\
\text { NT-pro-BNP at zero and six months: } \\
\text { Nebivolol Group = 147- } 152, p=0.77 \text {; Control } \\
\text { Group }=144-204, p=0.01 .\end{array}$ \\
\hline Bosch et al., 201313 & Barcelona, Spain & $\begin{array}{l}\text { Carvedilol + Enalapril } \\
(45)\end{array}$ & $\begin{array}{l}\text { Control group without } \\
\text { placebo (45) }\end{array}$ & $\begin{array}{l}\text { Intervention was superior. } \\
\text { Incidence of HF or reduction of LVEF> } \\
10 \% \text { : Intervention Group }=9.5 \% \text { vs. Control } \\
\text { Group }=19 \%, p=0.22 \text {. } \\
\text { Difference in LVEF variation between } \\
\text { groups: echocardiogram analysis }=-3.11 \text { ( } p \\
=0.04 \text { ); cardiac resonance analysis }=-3.40 \\
\text { ( } p=0.09 \text { ). } \\
\text { Death or HF: } 6.7 \% \text { vs. } 22.2 \% ; p=0.036 . \\
\text { Various chemotherapy drugs used - } \\
\text { unspecified on results in the group that } \\
\text { used anthracyclines ( } 40 \% \text { of Intervention } \\
\text { Group). }\end{array}$ \\
\hline Elitok et al., 201414 & Istanbul, Turkey & Carvedilol (40) & $\begin{array}{l}\text { Control group without } \\
\text { placebo (40) }\end{array}$ & $\begin{array}{l}\text { Intervention was superior. } \\
\text { LVEF after six months: Carvedilol Group } \\
=64.1 \% \text {, Control Group = } 63.3 \% ; p=N S ; \\
\text { systolic strain on the septal wall: Carvedilol } \\
\text { Group = 20.1, Control Group = } 16 ; p<0.005 \text {; } \\
\text { systolic strain on the lateral wall: Carvedilol } \\
\text { Group = } 18.2 \text {, Control Group }=14 ; p<0.005 \text {. }\end{array}$ \\
\hline $\begin{array}{l}\text { Tashakori Beheshti et al., } \\
201615\end{array}$ & Mashhad, Iran & Carvedilol (30) & $\begin{array}{l}\text { Control group without } \\
\text { placebo }(40)\end{array}$ & $\begin{array}{l}\text { Intervention was superior. Mean difference } \\
\text { in pre and post QT LVEF did not differ } \\
\text { between groups, but mean pre and post QT } \\
\text { strain of all walls was higher in the Control } \\
\text { Group. }\end{array}$ \\
\hline Jhorawat et al., 201616 & Chandigarh, India & Carvedilol (27) & $\begin{array}{l}\text { Control group without } \\
\text { placebo (27) }\end{array}$ & $\begin{array}{l}\text { Intervention was superior. } \\
\text { LVEF variation after six months: Carvedilol } \\
\text { Group }=+0.89 \% \text {, Control Group }=-7.74 \% \text {; } \\
p=0.003 . \\
\text { Variation of LV systolic diameter after six } \\
\text { months: Carvedilol Group }=+0.41 \mathrm{~mm} \text {, } \\
\text { Control Group }=+3.99 ; \mathrm{p}<0.05\end{array}$ \\
\hline Gulati et al., 201617 & $\begin{array}{l}\text { Lørenskog, } \\
\text { Norway }\end{array}$ & $\begin{array}{l}\text { Metoprolol + } \\
\text { Candesartan = 30; } \\
\text { Metoprolol + placebo } \\
=32(62)\end{array}$ & $\begin{array}{l}\text { Groups: Candesartan + } \\
\text { placebo (32); placebo + } \\
\text { placebo (32) }\end{array}$ & $\begin{array}{l}\text { No difference. } \\
\text { Mean LVEF reduction: without Metoprolol } \\
=1.8 \% \text { percentage point; } \text { with Metoprolol = } \\
1.6 \% \text { percentage point; } p=0.772 \text {. }\end{array}$ \\
\hline
\end{tabular}

$\mathrm{LVEF}=$ left ventricle ejection fraction; $\mathrm{HF}=$ heart failure; $\mathrm{NT}$-pro-BNP = N-terminal pro-B-type natriuretic peptide; $\mathrm{QT}=$ chemotherapy; $\mathrm{LV}=$ left ventricle

TABLE 2. SPECIFIC ANALYSIS OF EACH BETA-BLOCKER AGENT USED IN THE STUDIES INCLUDED IN THE SYSTEMATIC REVIEW

\begin{tabular}{l|l|l|l} 
Beta-blocker drug & Studies included & $\begin{array}{l}\text { Number of participants with } \\
\text { the beta-blocker in the studies }\end{array}$ & Results in the studies \\
\hline Carvedilol & $\begin{array}{l}\text { Kalay et al.10, Bosch et al.13, } \\
\text { Elitok et al.14, Tashakori } \\
\text { Beheshti et al.15, Jhorawat } \\
\text { et al.16 }\end{array}$ & $\begin{array}{l}\text { The five were positive, but two presented } \\
\text { differences only in the longitudinal strain, } \\
\text { and not in LVEF (Elitok et al.14, Tashakori } \\
\text { Beheshti et al.15) }\end{array}$ \\
\hline Metoprolol & $\begin{array}{l}\text { Georgakopoulos et al.11, } \\
\text { Gulati et al.17 }\end{array}$ & 87 & Both were negative. \\
\hline Kebivolol & Kaya et al.12 & Positive. \\
\hline
\end{tabular}




\section{DISCUSSION}

The high incidence of neoplasia is a worldwide trend due to several factors, including increased life expectancy, modern living habits and environmental pollution. Among the therapeutic arsenal of cancer treatment, anthracyclines are chemotherapeutics widely used in several neoplasms, with cardiotoxicity being one of its main adverse effects. ${ }^{2}$

In this systematic review, the main international scientific publications on the cardioprotective role of beta-blockers in preventing anthracycline cardiotoxicity were included and evaluated. Data obtained from the included clinical trials point to a potential cardioprotective function, but with limitations to a subclinical spectrum, in which a modest reduction of LVEF can be avoided after the use of chemotherapy. Still, some studies have limited themselves to finding benefits only in an even more restricted and precocious parameter, through the analysis of the strain through the echocardiogram. A reduction in left ventricular function is not always a predictor of heart failure, ${ }^{18}$ which raises questions about the outcomes used in clinical trials so far.

\section{Known cardioprotection mechanisms of beta-blockers}

For the development of an effective preventive strategy, several studies have attempted to clarify the pathophysiological mechanism of anthracycline cardiotoxicity. Oxidative stress and increased signalling for apoptosis are more frequent hypotheses, followed by thrombosis or vasospasm of coronary artery, as well as platelet aggregation induced by cisplatin $^{19-21}$. In addition to neurohumoral modulation, specific and individual actions of some beta-blocking agents could justify cardioprotection in the use of anthracyclines, but such data is scarce.

Carvedilol is a non-selective beta-blocker that also has action on alpha-1 receptors. ${ }^{22}$ It also has antioxidant effects and inhibits NADH-diaphorase (NADH-d). ${ }^{23}$ It has been shown that carvedilol is able to reduce the release of free radicals and apoptosis in cardiomyocytes after exposure to chemotherapeutic agents, preventing lipid peroxidation and increasing vitamin $\mathrm{E}$ concentrations. ${ }^{7,22,24,25}$

Nebivolol, a third-generation beta-blocker with high selectivity for beta-1 receptors, has cardioprotective properties via peripheral vasodilation mediated by nitric oxide, ${ }^{26}$ as well as antioxidant properties. ${ }^{27}$ In experimental studies with rats, antiapoptotic ef- fects on infarction and reduction of anthracycline

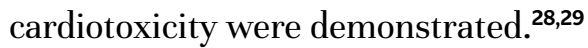

\section{Biases and limitations of studies included in} the review

Seven of the eight studies included in this review were published less than 10 years ago, which demonstrates relatively recent interest in the subject, even though cardiotoxicity associated with the use of anthracyclines has been known for decades. Historically, after the elucidation of pathophysiological mechanisms and once the relationship between cardiac lesion and chemotherapy with anthracyclines was established, some studies were conducted, but the scientific evidence is still timid, especially when compared to other relevant subjects in cardiology.

Since all the studies included in this analysis were unicentric and with a small sample size, there are limitations in the external validity for all of them, although similar results have been obtained in the majority. The main types of biases identified were those of measurement, as there were no standardized methods for the evaluation of the variables analysed. Selection and confounding biases were minimized by the clinical trial design common to all and by the exclusion criteria of each study. The four open-label, non-placebo-controlled studies (Jhorawat et al. $^{16}$, Elitok et al., ${ }^{14}$, Georgakopoulos et al., ${ }^{11}$ and Bosch et al. ${ }^{13}$ ) had their internal validity compromised due to potential biases from the lack of blinding (allocation confidentiality), which may compromise the reliability and validity of data. The follow-up time used in the studies makes it impossible to assess the anthracyclines for chronic cardiotoxicity, a common limitation to all studies included.

The study by Bosch et al. ${ }^{13}$ used the combination of carvedilol and enalapril as an intervention. Therefore, individual analysis of the beta-blocker in question becomes compromised. However, for the scientific value and methodological robustness, the study was included in the review, since it added value to the analysis of a beta-blocker as a potential cardioprotective agent in the use of anthracyclines. As for the study by Gulati et al. ${ }^{17}$, it was a double blind, placebo-controlled, randomized, $2 \times 2$ clinical trial, which analysed the drugs candesartan and metoprolol separately and combined in this setting. Results included individual analyses of the drugs in the allocated groups (candesartan-metoprolol, candesartan-placebo, metoprolol-placebo and placebo-placebo), allow- 
ing for the specific interpretation for the beta-blocker metoprolol in this systematic review.

The use of different criteria and measurements does not guarantee comparability between studies included. However, individual analyses of the studies can be very useful in view of the scarcity of robust scientific evidence on the subject. Regarding the echocardiographic parameter used, although the general reduction in LVEF was an important criterion for comparison, reductions to values lower than $50 \%$, that is, expressive drops that constitute left ventricular failure, would have greater clinical relevance.

In addition, the persistence of left ventricular dysfunction was not analysed in the vast majority of studies included, which were followed-up for only six months. Long-term results could strengthen the scientific consistency about the use of beta-blockers in this setting, with the potential to demonstrate continued and long-lasting benefits. The studies performed so far have presented an excellent capacity to generate a rational hypothesis with biological plausibility, with preliminary results considered satisfactory. However, there is a lack of normative studies and sufficient robustness to mark the routine use of beta-blockers in protocols to prevent anthracycline-induced cardiotoxicity.

Considerable heterogeneity within the beta-blocker class may be a confounding factor in this analysis, given the different pharmacological actions of the drugs in question. It is postulated that the activity of inhibiting free radicals is important in the prevention of cardiotoxicity by chemotherapy, and that this is offered in a different way among the agents of the class, especially carvedilol. Despite the scientific data more consistent with its use in relation to cardioprotective action, the ideal beta-blocking agent for clinical research and use is still undetermined. Due to the differences in pharmacokinetic properties between the agents studied and the absence of class effect, we considered that the meta-analysis would not be adequate, even though the intention of the analysis was the beta-blockers class in general.

\section{Other cardioprotective possibilities}

No study used bisoprolol as an intervention. This beta-blocker, as it has a preference for action on beta1 receptors and has high cardioselectivity, ${ }^{30}$ may be an option for future studies with potential cardioprotective action against myocardial injury caused by chemotherapeutic agents. Nebivolol, which had only one study included, also presents a more modern action, with potential vasculoprotective action, and should be the subject of further investigations.

To date, only the drug dexrazoxane has formal recommendation in some situations for the prevention of cardiotoxicity associated with anthracyclines. This drug, an iron chelator that prevents formation of the iron-doxorubicin complex, has been studied in this context since the $1980 \mathrm{~s}^{31-33}$. Satisfactory results have been observed in studies using dexrazoxane prior to chemotherapy with anthracyclines in different regimens. ${ }^{34-37}$ However, according to the clinical practice guideline of the 2008 American Society of Clinical Oncology, dexrazoxane should not be routinely used in combination with doxorubicin or other anthracyclines. Its use should be recommended only if a cumulative dose of doxorubicin greater than $300 \mathrm{mg} / \mathrm{m}^{2}$ in adults, if predicted to be of therapeutic benefit with even higher doses of chemotherapy. ${ }^{38}$ In Brazil, its use is limited in metastatic breast cancer when it occurs the use of high cumulative doses of anthracyclines. ${ }^{4}$

Other pharmacological classes have been studied as possible cardioprotectors against cardiotoxicity associated with anthracyclines. Inhibitors of angiotensin converting enzyme and angiotensin II receptor antagonists are drugs used and recommended in the therapeutic arsenal of heart failure and have, to date, weak scientific evidence of cardioprotection in chemotherapy. Some drugs were also analysed in studies selected for this review. While candesartan showed positive results in cardioprotective efficacy, ${ }^{17}$ enalapril demonstrated neutrality when used alone. ${ }^{11}$ Limitations of the evidence on these other classes keep beta-blockers one step ahead in relation to the volume of scientific information in this context.

The scientific gap in the topic extends to spironolactone, an aldosterone antagonist, also used in the treatment of heart failure. ${ }^{39}$ One study demonstrated the short-term effectiveness of this drug in the prevention of anthracycline-induced cardiotoxicity, ${ }^{40}$ however, despite the pharmacological rationale attractive, more studies are needed, especially in the long term. The combination of drugs with potential cardioprotective action, in turn, could offer a synergistic effect in the prevention of cardiotoxicity by chemotherapy, constituting a strategy to be considered in future studies. As with studies included in this review, ${ }^{13,17}$ the use of medications commonly used in the treatment of heart failure, administered 
in combination, represents a target of interest in clinical research, ${ }^{41}$ considering their pharmacological properties, the currently accessible cost of most of drugs and the low risk of serious adverse events.

This review brings scientific benefits on a relevant topic, and has the merits of evaluating the quality of evidence with recommended methods, but is also subject to bias. The selective reporting of complete studies in a systematic review may constitute publication bias, which should be reported as a potential limitation of this study. In the context of systematic reviews, outcome selective reporting, or outcome reporting bias, should also be considered, although the implications of the mentioned biases in the conduct and reporting of the reviews are unclear. The meta-analysis, considering only one of the beta-blocking agents, may be beneficial and configures the focus of future research in the search for answers on cardioprotection in chemotherapy treatment.

\section{CONCLUSIONS}

Beta-blockers represent a pharmacological class of interest in the prevention of anthracycline-associated cardiotoxicity. Existing scientific evidence, still incipient, exposes the need for a broader and more precise investigation. Analysing in detail the studies included in this review, it is concluded that beta-blockers have a potential cardioprotective action, yet to be definitively proven in larger studies, with long-term follow-up and using relevant clinical outcomes. Based on available scientific data, carvedilol, an agent of the class with the most evidence of benefit and with a greater number of patients evaluated, stands out. The dosage regimen and the optimal time of administration should still be defined, as well as the magnitude of the benefit of its use or of other beta-blockers, to allow the construction of future cardioprotective protocols in susceptible populations that will be submitted to the use of anthracyclines.

\section{Potential conflict of interest}

The authors declare that there is no relevant conflict of interest.

\section{Financing source}

The present study had no external sources of financing.

\section{Academic relation}

This article is part of the End of Course Paper of Taissa Borges Bourguignon, Luíza Dias Torres and Lorenza Silveira Arruda for graduation in Medicine from the School of Sciences of the Santa Casa de Misericórdia de Vitória (Emescam).

\section{APPENDIX 1. THE SEARCH STRATEGY USED IN MEDLINE/PUBMED WAS REPEATED ON THE OTHER DATABASES}

1. adult*tw

2. (cancer OR neoplas* OR malignan* ${ }^{*}$ OR tumor* $\mathrm{OR}$ solid tumor* OR blood tumor* OR hematopoietic tumor* OR lymphoid tumor* OR lymphoid malignan $\left.^{*}\right)$.ti,ab

3. (doxorubicin* OR adriamycin* OR daunorrubicin* OR epirrubicin* ${ }^{*}$ chemotherap*).ti,ab

4. (beta-block* OR carvedilol OR propranolol OR metoprolol OR bisoprolol OR atenolol OR nebivolol). ti,ab

5. (prevention OR prophylaxis).ti,ab

6. (cardiac $^{*}$ OR cardiac fail ${ }^{*}$ OR cardiac toxici* ${ }^{*}$ OR cardiotoxici* ${ }^{*}$ OR heart OR heart fail* ${ }^{*}$ OR cardiac dysfunction OR heart dysfunction OR cardiotoxicity OR cardiac toxicity OR cardiomyopathy). ti,ab

7. (systolic disfuntion OR diastolic disfunction OR myocardi* OR myocardial disfuntion OR cardioprotection).ti,ab

8. (clinical trial ${ }^{*}$ OR intervention ${ }^{*}$ OR interventional stud $^{*}$ OR cohort* OR cohort stud* OR historical cohort $^{*}$ OR case-control ${ }^{*}$ OR case-control stud ${ }^{*}$ OR observational stud*).tw

9. 1 AND 2 AND 3

10. 4 AND 5

11. 6 OR 7

12. 9 AND 10 AND 11

13. 8 AND 12

OBJETIVO: Este estudo teve como objetivo analisar o papel dos betabloqueadores na prevenção da cardiotoxicidade induzida pelas antraciclinas em adultos.

MÉTODOS: Foi realizada uma revisão sistemática em bases de dados eletrônicos, incluindo os estudos relevantes que analisaram fármacos betabloqueadores como agentes cardioprotetores antes do início do uso de antraciclinas por pacientes oncológicos adultos. 
RESULTADOS: Após aplicação dos critérios de elegibilidade e seleção, foram obtidos oito artigos considerados de boa qualidade, que se adequavam à temática proposta, sendo todos ensaios clínicos, quatro placebo-controlados, totalizando 655 pacientes incluídos. Destes, 281 (42,9\%) fizeram uso de algum betabloqueador como intervenção, sendo o carvedilol o mais utilizado (167 pacientes $25,5 \%$ ). Seis estudos foram considerados positivos quanto à cardioproteção exercida pelos betabloqueadores, porém apenas quatro demonstraram diferença na fração de ejeção do ventrículo esquerdo após a quimioterapia nos grupos que usaram betabloqueadores em relação aos grupos controle. O carvedilol e o nebivolol, mas não o metoprolol, tiveram resultados positivos quanto à cardioproteção. Outros betabloqueadores não foram avaliados nos estudos incluídos.

CONCLUSÕES: Apesar de haver um potencial efeito cardioprotetor dos betabloqueadores, conforme demonstrado em ensaios clínicos pequenos e unicêntricos, sua utilização rotineira na prevenção da cardiotoxicidade associada às antraciclinas requer maiores comprovações científicas.

PALAVRAS-CHAVE: Cardiotoxicidade. Antraciclinas. Insuficiência cardíaca. Cardiopatias/prevenção e controle.

\section{REFERENCES}

1. Gatta G, Capocaccia R, Coleman MP, Ries LA, Berrino F. Childhood cancer survival in Europe and the United States. Cancer. 2002;95(8):1767-72.

2. Wojtacki J, Lewicka-Nowak E, Lesniewski-Kmak K. Anthracycline-induced cardiotoxicity: clinical course, risk factors, pathogenesis, detection and prevention - review of the literature. Med Sci Monit. 2000;6(2):41120.

3. Vejpongsa P, Yeh ET. Prevention of anthracycline-induced cardiotoxicity: challenges and opportunities. J Am Coll Cardiol. 2014;64(9):938-45.

4. Kalil Filho R, Hajjar LA, Bacal F, Hoff PMG, Diz MDPS, Galas FRBG, et al. I diretriz brasileira de cardio-oncologia da Sociedade Brasileira de Cardiologia. Arq Bras Cardiol. 2011;96(2 supl. 1):1-52.

5. Matos Neto RP, Petrilli AS, Silva CM, Campos Filho O, Oporto VM, Gomes LF, et al. Left ventricular systolic function assessed by echocardiography in children and adolescents with osteosarcoma treated with doxorubicin alone or in combination with dexrazoxane. Arq Bras Cardiol. 2006;87(6):763-71

6. Harake D, Franco VI, Henkel JM, Miller TL, Lipshultz SE. Cardiotoxicity in childhood cancer survivors: strategies for prevention and management. Future Cardiol. 2012;8(4):647-70.

7. Lipshultz SE, Sambatakos P, Maguire M, Karnik R, Ross SW, Franco VI, et al. Cardiotoxicity and cardioprotection in childhood cancer. Acta Haematol. 2014;132(3-4):391-9.

8. Ponikowski P, Voors AA, Anker SD, Bueno H, Clelan JGF, Coats AJS, et al; ESC Scientific Document Group. 2016 ESC Guidelines for the diagnosis and treatment of acute and chronic heart failure: The Task Force for the diagnosis and treatment of acute and chronic heart failure of the European Society of Cardiology (ESC)Developed with the special contribution of the Heart Failure Association (HFA) of the ESC. Eur Heart J. 2016;37(27):2129200.

9. Moher D, Liberati A, TetzlaffJ, Altman DG, The PRISMA Group. Preferred reporting items for systematic reviews and meta-analyses: the PRISMA Statement. Disponível em: www.prisma-statement.org.

10. Kalay N, Basar E, Ozdogru I, Er O, Cetinkaya Y, Dogan A, et al. Protective effects of carvedilol against anthracycline-induced cardiomyopathy. I Am Coll Cardiol. 2006;48(11):2258-62.

11. Georgakopoulos P, Roussou P, Matsakas E, Karavidas A, Anagnostopoulos $N$, Marinakis T, et al. Cardioprotective effect of metoprolol and enalapril in doxorubicin-treated lymphoma patients: a prospective, parallel-group, randomized, controlled study with 36-month follow-up. Am J Hematol. 2010;85(11):894-6

12. Kaya MG, Ozkan M, Gunebakmaz O, Akkaya H, Kaya EG, Akpek M, et al. Protective effects of nebivolol against anthracycline-induced cardiomyopathy: a randomized control study. Int | Cardiol. 2013;167(5):2306-10.

13. Bosch $X$, Rovira M, Sitges $M$, Domènech A, Ortiz-Pérez JT, Caralt TM, et al. Enalapril and carvedilol for preventing chemotherapy-induced left ventricular systolic dysfunction in patients with malignant hemopathies: the OVERCOME trial (preventiOn of left Ventricular dysfunction with Enalapril and caRvedilol in patients submitted to intensive ChemOtherapy for the treatment of Malignant hEmopathies). I Am Coll Cardiol. 2013;61(23):2355-62.

14. Elitok $A, O z F$, Cizgici AY, Kilic L, Ciftci R, Sen F, et al. Effect of carvedilol on silent anthracycline-induced cardiotoxicity assessed by strain imaging: a prospective randomized controlled study with six-month follow-up. Cardiol J. 2014;21(5):509-15.
15. Tashakori Beheshti A, Mostafavi Toroghi H, Hosseini G, Zarifian A, Homaei Shandiz F, Fazlinezhad A. Carvedilol administration can prevent doxorubicin-induced cardiotoxicity: a double-blind randomized trial. Cardiology. 2016;134(1):47-53

16. Jhorawat R, Kumari S, Varma SC, Rohit MK, Narula M, Suri V, et al. Preventive role of carvedilol in adriamycin-induced cardiomyopathy. Indian I Med Res. 2016;144(5):725-9.

17. Gulati G, Heck SL, Ree AH, Hoffmann P, Schulz-Menger J, Fagerland $M W$, et al. Prevention of cardiac dysfunction during adjuvant breast cancer therapy (PRADA): a $2 \times 2$ factorial, randomized, placebo-controlled, double-blind clinical trial of candesartan and metoprolol. Eur Heart ). 2016;37(21):1671-80.

18. Swain SM, Whaley FS, Ewer MS. Congestive heart failure in patients treated with doxorubicin: a retrospective analysis of three trials. Cancer. 2003;97(1):2869-79.

19. Octavia Y, Tocchetti CG, Gabrielson KL, Janssens S, Crijns HJ, Moens AL. Doxorubicin-induced cardiomyopathy: from molecular mechanisms to therapeutic strategies. J Mol Cell Cardiol. 2012;52(6):1213-25.

20. Arola OJ, Saraste A, Pulkki K, Kallajoki M, Parvinen M, Voipio-Pulkki LM. Acute doxorubicin cardiotoxicity involves cardiomyocyte apoptosis. Cancer Res. 2000;60(7):1789-92.

21. Schimmel KJ, Richel DJ, van den Brink RB, Guchelaar HJ. Cardiotoxicity of cytotoxic drugs. Cancer Treat Rev. 2004;30(2):181-91.

22. Machado V, Cabral A, Monteiro P, Gonçalves L, Providência LA. Carvedilol as a protector against the cardiotoxicity induced by anthracyclines (doxorubicin). Rev Port Cardiol. 2008;27(10):1277-96.

23. Cheng J, Kamiya K, Kodama I. Carvedilol: molecular and cellular basis for its multifaceted therapeutic potential. Cardiovasc Drug Rev. 2001;19(2):15271.

24. Spallarossa P, Garibaldi S, Altieri P, Fabbi P, Manca V, Nasti S, et al. Carvedilol prevents doxorubicin-induced free radical release and apoptosis in cardiomyocytes in vitro. J Mol Cell Cardiol. 2004;37(4):837-46.

25. El-Shitany AN, Tolba AO, El-Shanshory RM, El-Hawary EE. Protective effect of carvedilol on adriamycin-induced left ventricular dysfunction in children with acute lymphoblastic leukemia. J Card Fail. 2012;18(8):60713 .

26. Shibata MC, Flather MD, Böhm M, Borbola J, Cohen-Solal A, Dumitrascu $D$, et al; Study of the Effects of Nebivolol Intervention on Outcomes and Rehospitalisation in Seniors with heart failure (SENIORS). Rationale and design. Inter J Cardiol. 2002;86(1):77-85.

27. Münzel T, Gori T. Nebivolol: the somewhat-different beta-adrenergic receptor blocker. J Am Coll Cardiol. 2009;54(16):1491-9.

28. Groot AA, Mathy MJ, van Zwieten PA, Peters SL. Antioxidant activity of nebivolol in the rat aorta. J Cardiovasc Pharmacol. 2004;43(1):148-53.

29. Nigris F, Rienzo M, Schiano C, Fiorito C, Casamassimi A, Napoli C. Prominent cardioprotective effects of third generation beta blocker nebivolol against anthracycline-induced cardiotoxicity using the model of isolated perfused rat heart. Eur J Cancer. 2008;44(3):334-40.

30. Luna RL, Oigman W, Ramirez JA, Mion D, Batlouni M, Rocha JC, et al. Eficácia e tolerabilidade da associação bisoprolol/hidroclorotiazida na hipertensão arterial. Arq Bras Cardiol. 1998;71(4):601-8.

31. Blum RH. Clinical status and optimal use of the cardioprotectant, dexrazoxane. Oncology (Williston Park). 1997;11(11):1669-77. 
32. Hellmann K. Cardioprotection by dexrazoxane (Cardioxane; ICRF 187): progress in supportive care. Support Care Cancer. 1996;4(4):305-7.

33. Fulbright JM, Huh W, Anderson P, Chandra J. Can anthracycline therapy for pediatric malignancies be less cardiotoxic? Curr Oncol Rep. 2010;12(6):411-9.

34. larussi D, Indolfi P, Casale F, Martino V, Di Tullio MT, Calabrò R. Anthracycline-induced cardiotoxicity in children with cancer: strategies for prevention and management. Paediatr Drugs. 2005;7(2):67-76.

35. Chatterjee K, Zhang J, Honbo N, Karliner JS. Doxorubicin cardiomyopathy. Cardiology. 2010;115(2):155-62.

36. Cvetkovic RS, Scott LJ. Dexrazoxane: a review of its use for cardioprotection during anthracycline chemotherapy. Drugs. 2005;65(7):1005-24.

37. Paiva MG, Petrilli AS, Moisés VA, Macedo CR, Tanaka C, Campos O. Cardioprotective effect of dexrazoxane during treatment with doxorubicin: a study using low-dose dobutamine stress echocardiography. Pediatr Blood Cancer. 2005;45(7):902-8
38. Hensley ML, Hagerty KL, Kewalramani T, Green DM, Meropol NJ, Wasserman TH, et al. American Society of Clinical Oncology 2008 clinical practice guideline update: use of chemotherapy and radiation therapy protectants. J Clin Oncol. 2009;27(1):127-45.

39. Pitt B, Zannad F, Remme WJ, Cody R, Castaigne A, Perez A, et al. The effect of spironolactone on morbidity and mortality in patients with severe heart failure. Randomized Aldactone Evaluation Study Investigators. N Engl J Med. 1999;341(10):709-17.

40. Akpek M, Ozdogru I, Sahin O, Inanc M, Dogan A, Yazici C, et al. Protective effects of spironolactone against anthracycline-induced cardiomyopathy. Eur | Heart Fail. 2015;17(1):81-9.

41. Meattini I, Curigliano G, Terziani F, Becherini C, Airoldi M, Allegrin $G$, et al. SAFE trial: an ongoing randomized clinical study to assess the role of cardiotoxicity prevention in breast cancer patients treated with anthracyclines with or without trastuzumab. Med Oncol. 2017;34(5):75. 